\title{
Patient experiences and health system responsiveness in South Africa
}

\author{
Karl Peltzer ${ }^{1,2}$
} Address: ${ }^{1}$ Health Promotion Research Unit, Social Aspect of HIV/AIDS and Health, Human Sciences Research Council, Pretoria, South Africa and
2Department of Psychology, University of the Free State, Bloemfontein, South Africa

Email: Karl Peltzer - kpeltzer@hsrc.ac.za

Published: I4 July 2009

BMC Health Services Research 2009, 9:I I7 doi:10.1 186/1472-6963-9-1 I7

This article is available from: http://www.biomedcentral.com/1472-6963/9/1 I7

(c) 2009 Peltzer; licensee BioMed Central Ltd.

This is an Open Access article distributed under the terms of the Creative Commons Attribution License (http://creativecommons.org/licenses/by/2.0), which permits unrestricted use, distribution, and reproduction in any medium, provided the original work is properly cited.
Received: 15 January 2009

Accepted: 14 July 2009

\begin{abstract}
Background: Patients' views are being given more and more importance in policy-making. Understanding populations' perceptions of quality of care is critical to developing measures to increase the utilization of primary health care services. Using the data from the South African World Health Survey (WHS), the current study aims to evaluate the degree of health care service responsiveness (both out-patient and in-patient) and comparing experiences of individuals who used public and private services in South Africa.
\end{abstract}

Methods: A population-based survey of 2352 participants (III6 men and 1236 women) was conducted in South Africa in 2003, the WHS - as part of a World Health Organization (WHO) project focused on health system performance assessment in member countries.

Results: Health care utilization was among those who attended in-patient care $72.2 \%$ attended a public and $24.3 \%$ a private facility, and of those who attended out-patient care $58.7 \%$ attended a public and $35.7 \%$ a private facility. Major components identified for out-patient care responsiveness in this survey were highly correlated with health care access, communication and autonomy, secondarily to dignity, confidentiality and quality of basic amenities, and thirdly to health problem solution. The degree of responsiveness with publicly provided care was in this study significantly lower than in private health care. Overall patient non-responsiveness for the public out-patient service was $16.8 \%$ and $3.2 \%$ for private care. Discrimination was also one of the principal reasons for non-responsiveness in all aspects of provided health care.

Conclusion: Health care access, communication, autonomy, and discriminatory experiences were identified as priority areas for actions to improve responsiveness of health care services in South Africa.

\section{Background}

The majority of South Africans depend on the public health sector for their health care needs [1]; the percentage of adults who reported that they have medical aid in the Demographic and Health Survey in 2003 was 14.2\% [2]. Shisana et al. [3] found in a nationally representative survey that the majority $(70 \%)$ indicated that they usually attended public health care services, while $23.3 \%$ attended private health care services, and a small proportion $(0.1 \%)$ utilised traditional health practitioners. In many areas of South Africa, the Primary Health Care (PHC) facilities are the only available or easily accessible health service for local communities. As a result, PHC services, providers and facilities carry a large burden and 
responsibility for the provision of health care in South Africa. PHC is the basic mechanism for providing health care [4]. It was formally introduced in South Africa in April 1994 as the major principle for health care provision with the implementation of two policies, "Free health care for pregnant mothers and children under the age of six years" as well the "Universal Access to PHC for All South Africans" [4]. The Department of Health's strategic framework for 2002-2004 identifies improvements of quality of care as one of the four key challenges currently facing the health sector in South Africa [5]. Quality of care is concerned with the interface between provider and patients, between health services and community. A quality perspective changes the focus of health systems development from establishing structures to addressing what happens in the structures. Improving quality can, therefore, be regarded as a second phase of health care transformation in South Africa. The first phase was concerned with creating coherent health care structures and the second phase with ensuring quality of service delivery [5].

Variations in the perception of quality occur as a result of the heterogeneous nature of the definition of quality. Studies have pointed to variations in perception of quality by different socioeconomic groups as well as the environmental aspects such as the social, organisational and technological context of the service [6]. Van Vuuren and Botes [7] found among a culturally diverse population in an urban area in South Africa (greater Bloemfontein) that variables such as population group, age and employment status influence their attitudes towards professional health care. They further emphasise the importance of bringing these issues to the attention of health care policy makers. Peltzer [8] found in a community survey in rural South Africa a low acceptability of primary health care: $78 \%$ felt that the medical services are poor. Bediako, Nel and Hiemstra [9] found among hospital and out-patients in the North-West Province that more than half of the patients $(56.8 \%)$ were not satisfied with the availability of medicines and other supplies. Approximately two thirds of patients $(65.2 \%)$ did not know about the quality of telephone services rendered. There was a high level of dissatisfaction (63.1\%) among patients regarding accessing doctors after hours. Most patients were satisfied with the general attitude of health workers (62.1\%) but $21.2 \%$ were dissatisfied. De Jager and Du Plooy [10] found among in- and out-patients in a provincial hospital in Gauteng significant differences between in- and outpatients. Personal safety and cleanliness of facilities were regarded as the most important variables in the assurance and tangibility dimensions. The level of satisfaction was the highest for clear information and communication at an understandable level in the tangibility and assurance categories, respectively. The South African Department of Health [2] found that there was an increase in the percent- age of adults who expressed dissatisfaction with all types of health services, except for traditional healers, comparing the Demographic and Health Survey (DHS) of 1998 and 2003. Generally, the results show that considerably more people are dissatisfied with the services rendered in hospitals, both public (23.3\%) and private (11.6\%). Even the levels of dissatisfaction with the services rendered by solo practitioners in the private sector $(7.9 \%)$ seem to be on the increase during the period between the surveys. The major reasons for dissatisfaction with the public sector hospitals and community health centres were long waiting times (41.5\% and $38.1 \%$ respectively), staff attitudes (22.8\% and $25.9 \%$ respectively), non-availability of prescribed medication ( $15.8 \%$ and $17.7 \%$ respectively) and shortages of staff (doctors/pharmacists). Major reasons for dissatisfaction in the private hospital/clinic sector and private doctor were also long waiting times $(26.7 \%$ and $7.4 \%$ respectively), staff attitude $(18.0 \%$ and $7.1 \%$ respectively), and cost (15.2\% and $24.8 \%$ respectively) [2]. Myburgh, Solanki, Smith and Lalloo [11] used a 1998 national population-based survey and found that both race and socio-economic status (SES) were significant predictors of levels of satisfaction with the services of the health care provider; White and high SES respondents were about 1.5 times more likely to report excellent service compared with African Black and low SES respondents, respectively.

Patients' views are being given more and more importance in policy-making. Understanding populations' perceptions of quality of care is critical to developing measures to increase the utilization of primary health care services.

A population-based survey was conducted in South Africa in 2003, the WHS - as part of a WHO project focused on health system performance assessment in member countries. Among the surveyed aspects was the evaluation of health care provision, based on the concept of "responsiveness" [12]. Using the data from the South African WHS, the current study aims to evaluate the degree of responsiveness with provided health care (both outpatient and in-patient), and comparing the experiences of individuals who used public and private services in South Africa.

\section{Methods}

\section{Sample and procedure}

The country sample $(\mathrm{n}=2352)$ was nationally representative and probabilistically selected using a multistage cluster design. All respondents were selected using a Kish table for selection within a household. The study included: (1) all individuals who had been hospitalized in the previous five years (stayed overnight in a hospital or other type of long-term care facility), and (2) among those who had not 
Table I: Last visit responsiveness in percent by public or private out-patient care $(n=424$, excluding NGO and other: $n=25)$

\begin{tabular}{|c|c|c|c|c|}
\hline Out-patient care & $\begin{array}{l}\text { Total } \\
(n=424)\end{array}$ & $\begin{array}{l}\text { Public } \\
(n=267)\end{array}$ & $\begin{array}{l}\text { Private } \\
(n=157)\end{array}$ & OR $(95 \% \mathrm{Cl})$ \\
\hline Age (Mean) & 37.6 & 41.0 & 36.6 & $\begin{array}{l}\text { Public }=1.00 \\
\text { Private }=1.02(1.01-1.04)^{* *}\end{array}$ \\
\hline Female patient & 61.6 & 69.1 & 49.2 & $\begin{array}{l}\text { Public }=1.00 \\
\text { Private }=2.31(1.49-3.59)^{* * *}\end{array}$ \\
\hline Education (Mean, range I-7) & 3.8 & 3.3 & 4.7 & $\begin{array}{l}\text { Public }=1.00 \\
\text { Private }=0.56(0.48-0.66)^{* * *}\end{array}$ \\
\hline Seen by medical doctor & 53.5 & 36.6 & 81.7 & $\begin{array}{l}\text { Public }=1.00 \\
\text { Private }=0.13(0.08-0.22)^{* * *}\end{array}$ \\
\hline Time to get to facility in minutes (Mean) & 29.3 & 33.5 & 21.0 & $\begin{array}{l}\text { Public }=1.00 \\
\text { Private }=1.02(1.00-1.04)^{*}\end{array}$ \\
\hline Provider fees (Mean in Rand) & 37.5 & 16.1 & 150.1 & $\begin{array}{l}\text { Public }=1.00 \\
\text { Private }=0.98(0.97-0.99)^{* *}\end{array}$ \\
\hline Medicines costs (Mean in Rand) & 16.2 & 6.5 & 38.1 & $\begin{array}{l}\text { Public }=1.00 \\
\text { Private }=0.97(0.94-1.00)^{*}\end{array}$ \\
\hline \multicolumn{5}{|l|}{ Patient satisfaction } \\
\hline I. Traveling time to the health care provider & 64.6 & 54.3 & 81.0 & $\begin{array}{l}\text { Public }=1.00 \\
\text { Private }=0.28(0.17-0.46)^{* * *}\end{array}$ \\
\hline 2. Waiting time & 51.2 & 36.2 & 75.4 & $\begin{array}{l}\text { Public }=1.00 \\
\text { Private }=0.19(0.12-0.30)^{* * *}\end{array}$ \\
\hline 3. Being greeted and talked to respectfully & 69.2 & 59.7 & 84.7 & $\begin{array}{l}\text { Public }=1.00 \\
\text { Private }=0.81(0.26-2.48)\end{array}$ \\
\hline 4. Respect for intimacy during physical examination & 73.6 & 65.2 & 87.2 & $\begin{array}{l}\text { Public }=1.00 \\
\text { Private }=0.60(0.18-1.99)\end{array}$ \\
\hline 5. Clarity of explanations & 73.2 & 63.6 & 88.9 & $\begin{array}{l}\text { Public }=1.00 \\
\text { Private }=0.22(0.12-0.39)^{* * *}\end{array}$ \\
\hline 6. Time for questions & 64.5 & 52.7 & 83.7 & $\begin{array}{l}\text { Public }=1.00 \\
\text { Private }=0.22(0.13-0.37)^{* * *}\end{array}$ \\
\hline 7. Possibility of obtaining information on other types of treatment & 61.0 & 49.2 & 80.2 & $\begin{array}{l}\text { Public }=1.00 \\
\text { Private }=0.24(0.15-0.39) * * *\end{array}$ \\
\hline 8. Participation in treatment decision-making & 58.0 & 48.5 & 73.5 & $\begin{array}{l}\text { Public }=1.00 \\
\text { Private }=0.34(0.21-0.54)^{* * *}\end{array}$ \\
\hline 9. Privacy with health professionals & 68.7 & 59.5 & 83.6 & $\begin{array}{l}\text { Public }=1.00 \\
\text { Private }=0.29(0.17-0.49)^{* * *}\end{array}$ \\
\hline 10. Confidentiality of personal information & 78.4 & 71.1 & 89.7 & $\begin{array}{l}\text { Public }=1.00 \\
\text { Private }=0.28(0.15-0.54)^{* * *}\end{array}$ \\
\hline II. Freedom to choose health care provider & 56.9 & 42.2 & 80.8 & $\begin{array}{l}\text { Public }=1.00 \\
\text { Private }=0.17(0.11-0.28)^{* * * *}\end{array}$ \\
\hline
\end{tabular}


Table I: Last visit responsiveness in percent by public or private out-patient care $(n=424$, excluding NGO and other: $n=25)$ (Continued)

\begin{tabular}{|c|c|c|c|c|}
\hline 12. Cleanliness inside the health facility & 72.7 & 62.6 & 89.1 & $\begin{array}{l}\text { Public }=1.00 \\
\text { Private }=0.21(0.11-0.38)^{* * *}\end{array}$ \\
\hline 13. Available space in waiting and examination rooms & 63.3 & 51.1 & 83.1 & $\begin{array}{l}\text { Public }=1.00 \\
\text { Private }=0.21(0.13-0.36)^{* * *}\end{array}$ \\
\hline 14. Satisfactory health care provider skills & 92.3 & 89.1 & 97.7 & $\begin{array}{l}\text { Public }=1.00 \\
\text { Private }=0.32(0.13-0.81)^{*}\end{array}$ \\
\hline 15. Adequate equipment & 91.6 & 89.5 & 94.9 & $\begin{array}{l}\text { Public }=1.00 \\
\text { Private }=0.52(0.24-1.13)\end{array}$ \\
\hline 16. Adequate availability of medicines & 87.1 & 84.6 & 91.0 & $\begin{array}{l}\text { Public }=1.00 \\
\text { Private }=0.52(0.31-1.08)\end{array}$ \\
\hline Total mean responsiveness (range $0-16$ ) & 11.4 & 9.8 & 13.6 & $\begin{array}{l}\text { Public }=1.00 \\
\text { Private }=0.78(0.73-0.83)^{* * *}\end{array}$ \\
\hline
\end{tabular}

$* * * \mathrm{P}<.001 ; * * \mathrm{P}<.01 ; * \mathrm{P}<.05$

been hospitalized in the previous five years, all individuals who had used an out-patient health service in the past 12 months. Only the participants who had used an inpatient and/or out-patient health services were requested to complete the responsiveness questions. The number of responses obtained was a function of the overall response rate as well as the rate of service utilization in the previous 12 months for out-patient and 5 years for in-patient services. More detailed information about the World Health Survey is available on its website http://www.who.int/ healthinfo/survey/en/index.html. To adjust for the population distribution as represented by the UN Statistical Division and for non-response, post-stratification corrections were made to the sampling weights.

Participants were interviewed face-to-face by lay people with at least a high school-level education; interviewers were trained in a week-long course using a standard manual and audiovisual aids as well as role-plays. Practice field interviews were reviewed by supervisors before actual data collection. All questionnaires were translated into major languages in South Africa and back-translated using a standard WHO protocol. The quality of translations was independently verified by bilingual experts before field implementation. Informed consent was obtained from all respondents and the study was cleared by ethics review committees.

\section{Outcome measures}

The questionnaire included in this analysis used the health system responsiveness module. Responsiveness relates to patient's experiences with the health system, with a focus on the interpersonal aspects of the care, and differs from patient satisfaction, a construct that reflects people's expectations in addition to their experiences [13].
Questions covered the following aspects: traveling time to the health care provider (item wording: For your last visit [or hospital stay], how would you rate the traveling time to the health care provider [or hospital]?); waiting time before being attended to; being greeted and talked to respectfully; respect for intimacy during physical examination and care; clarity of explanations by the health care providers; availability of time to ask questions about the health problem or treatment; possibility of obtaining information on other types of treatment or tests; participation in decision-making on the health care or treatment; patient's freedom to speak privately with the health professionals; personal information kept confidential; freedom to choose the health care provider; inside the facility cleanliness including toilets; and available space in waiting and examination rooms. For participants who received in-patient care, two additional aspects were included: ease in receiving visits by family members (item wording: For your last hospital stay, how would you rate the ease of having family and friends visit you? and contact with the outside world) [13]. Response options for these responsiveness items were $1=$ very good, $2=\operatorname{good}$, $3=$ moderate, $4=$ bad, and $5=$ very bad. These item responses were dichotomised into " 1 " and " 2 " = 1, and 3$5=0$. In addition, there were three items for both outpatients and in-patients related to the health professional's skills (item wording for out-patients: In your opinion was the health care provider's skill adequate for your treatment? and item wording for in-patients: In your opinion, was the skill of the health care providers adequate for your treatment?), availability of medicines, and adequacy of equipment in the care; response options for these items were "yes" or "no". Cronbach alpha for the 16 items out-patients responsiveness scale was .89 for this sample and for the 18 items in-patient responsiveness scale .90 for this sample. Further, participants were asked 
Table 2: Last visit responsiveness in percent by public and private in-patient care $(n=633$, excluding NGO and other: $n=23)$

\begin{tabular}{|c|c|c|c|c|}
\hline In-patient care & $\begin{array}{l}\text { Total } \\
(n=633)\end{array}$ & $\begin{array}{l}\text { Public } \\
(n=472)\end{array}$ & $\begin{array}{l}\text { Private } \\
(n=16 \mid)\end{array}$ & OR $(95 \% \mathrm{Cl})$ \\
\hline Age (Mean) & 38.9 & 38.7 & 39.4 & $\begin{array}{l}\text { Public }=1.00 \\
\text { Private }=0.99(0.98-1.05)\end{array}$ \\
\hline Female patient & 60.4 & 63.3 & 51.7 & $\begin{array}{l}\text { Public }=1.00 \\
\text { Private }=1.61(1.49-3.59)^{*}\end{array}$ \\
\hline Education (Mean, range I-7) & 3.9 & 3.5 & 5.1 & $\begin{array}{l}\text { Public }=1.00 \\
\text { Private }=0.40(0.34-0.48)^{* * *}\end{array}$ \\
\hline Time to get to facility in minutes & 37 & 42 & 26 & $\begin{array}{l}\text { Public }=1.00 \\
\text { Private }=1.02(1.00-1.03)^{*}\end{array}$ \\
\hline Provider fees (in Rand) & 246 & 44 & 907 & $\begin{array}{l}\text { Public }=1.00 \\
\text { Private }=0.99(0.99-1.00)^{* * *}\end{array}$ \\
\hline Medicines costs (in Rand) & 78 & 9 & 299 & $\begin{array}{l}\text { Public }=1.00 \\
\text { Private }=0.99(0.98-0.99)^{* * *}\end{array}$ \\
\hline Tests & 32 & 7 & 115 & $\begin{array}{l}\text { Public }=1.00 \\
\text { Private }=0.99(0.99-1.00)^{* *}\end{array}$ \\
\hline Transport & 37 & 41 & 24 & $\begin{array}{l}\text { Public }=1.00 \\
\text { Private }=1.00(0.99-1.01)\end{array}$ \\
\hline Number of people slept in same room (Mean) & 5.8 & 6.6 & 3.5 & $\begin{array}{l}\text { Public }=1.00 \\
\text { Private }=1.22(1.06-1.40)^{* *}\end{array}$ \\
\hline \multicolumn{5}{|l|}{ Patient satisfaction } \\
\hline I. Traveling time to the health care provider & 67.8 & 61.2 & 87.5 & $\begin{array}{l}\text { Public }=1.00 \\
\text { Private }=0.23(0.14-0.38)^{* * *}\end{array}$ \\
\hline 2. Waiting time & 63.3 & 55.2 & 87.1 & $\begin{array}{l}\text { Public }=1.00 \\
\text { Private }=0.18(0.1 \mid-0.31)^{* * *}\end{array}$ \\
\hline 3. Being greeted and talked to respectfully & 70.6 & 63.3 & 92.0 & $\begin{array}{l}\text { Public }=1.00 \\
\text { Private }=0.15(0.08-0.28)^{* * *}\end{array}$ \\
\hline 4. Respect for intimacy during physical examination & 77.9 & 72.1 & 94.5 & $\begin{array}{l}\text { Public }=1.00 \\
\text { Private }=0.14(0.07-0.30)^{* * * *}\end{array}$ \\
\hline 5. Clarity of explanations & 71.0 & 63.9 & 91.7 & $\begin{array}{l}\text { Public }=1.00 \\
\text { Private }=0.16(0.08-0.31)^{* * *}\end{array}$ \\
\hline 6. Time for questions & 63.0 & 55.0 & 86.4 & $\begin{array}{l}\text { Public }=1.00 \\
\text { Private }=0.19(0.11-0.33)^{* * * *}\end{array}$ \\
\hline 7. Possibility of obtaining information on other types of treatment & 61.2 & 53.4 & 84.6 & $\begin{array}{l}\text { Public }=1.00 \\
\text { Private }=0.21(0.13-0.35)^{* * *}\end{array}$ \\
\hline 8. Participation in treatment decision-making & 60.6 & 50.4 & 90.6 & $\begin{array}{l}\text { Public }=1.00 \\
\text { Private }=0.11(0.06-0.19)^{* * *}\end{array}$ \\
\hline 9. Privacy with health professionals & 69.5 & 62.3 & 91.0 & $\begin{array}{l}\text { Public }=1.00 \\
\text { Private }=0.16(0.09-0.30)^{* * *}\end{array}$ \\
\hline
\end{tabular}


Table 2: Last visit responsiveness in percent by public and private in-patient care $(n=633$, excluding NGO and other: $n=23)$ (Continued)

\begin{tabular}{|c|c|c|c|c|}
\hline 10. Confidentiality of personal information & 76.9 & 71.3 & 93.0 & $\begin{array}{l}\text { Public }=1.00 \\
\text { Private }=0.19(0.10-0.36)^{* * *}\end{array}$ \\
\hline II. Freedom to choose health care provider & 55.7 & 45.8 & 84.4 & $\begin{array}{l}\text { Public }=1.00 \\
\text { Private }=0.11(0.09-0.26)^{* * *}\end{array}$ \\
\hline 12. Cleanliness inside the health facility & 72.6 & 65.8 & 92.6 & $\begin{array}{l}\text { Public }=1.00 \\
\text { Private }=0.15(0.08-0.30)^{* * *}\end{array}$ \\
\hline 13. Available space in waiting and examination rooms & 67.8 & 60.0 & 90.9 & $\begin{array}{l}\text { Public }=1.00 \\
\text { Private }=0.12(0.07-0.22)^{* * *}\end{array}$ \\
\hline 14. Satisfactory health care provider skills & 93.7 & 92.3 & 97.8 & $\begin{array}{l}\text { Public }=1.00 \\
\text { Private }=0.29(0.09-0.88)^{* * *}\end{array}$ \\
\hline 15. Adequate equipment & 91.8 & 89.9 & 97.2 & $\begin{array}{l}\text { Public }=1.00 \\
\text { Private }=0.26(0.10-0.72)^{* *}\end{array}$ \\
\hline 16. Adequate availability of medicines & 89.7 & 87.8 & 95.3 & $\begin{array}{l}\text { Public }=1.00 \\
\text { Private }=0.44(0.22-0.86)^{*}\end{array}$ \\
\hline 17. Ease of receiving visitors & 73.9 & 67.1 & 94.1 & $\begin{array}{l}\text { Public }=1.00 \\
\text { Private }=0.13(0.06-0.26)^{* * *}\end{array}$ \\
\hline 18. Ease of staying in contact with outside world & 62.4 & 52.9 & 90.3 & $\begin{array}{l}\text { Public }=1.00 \\
\text { Private }=0.12(0.08-0.88)^{* * *}\end{array}$ \\
\hline Total mean responsiveness (range $0-18$ ) & 12.9 & 11.7 & 16.3 & $\begin{array}{l}\text { Public }=1.00 \\
\text { Private }=0.70(0.64-0.77)^{* * * *}\end{array}$ \\
\hline
\end{tabular}

$* * * \mathrm{P}<.001 ; * * \mathrm{P}<.01 ; * \mathrm{P}<.05$

whether they felt they had been treated worse by the health care providers (whether they felt discriminated) for on any of the following reasons: sex, age, lack of money, social class, ethnic group or skin color, type of illness, or nationality. Response options for these 7 items were "yes" or "no" [13].

\section{Data analysis}

The first stage of this work included a descriptive analysis of the degree of responsiveness based on a set of variables that expressed the user's degree of experience, according to five response levels $(1=$ very good to $5=$ very bad $)$. For each of the items, the degree of responsiveness was estimated by the percentage of "good" or "very good" answers and the percentage of positive answers to three other dichotomous variables (yes or no), related to the health professional's skills, availability of medicines, and adequacy of equipment in the care. Percentages of patients' experiences were analyzed by "type of care" (out-patient or in-patient) and by public and private health care service utilization [13].

To explain total variation in the data set using a smaller number of factors, the second stage of the analysis used principal component analysis with varimax rotation.
Logistic regression was conducted for public versus private health care provider, and linear regression for the total responsiveness scale (16 responsiveness items for outpatients and 18 responsiveness items for in-patients), separately for public and private health care utilization. Demographic variables included sex, two age groups (18 to 39 and 40 years and above), two educational groups (up to primary school completed and above) [13], discriminatory experiences were summed up and converted into a binary variable with $1=$ indicating any of the six discriminatory experiences and $0=$ no such experiences.

For the statistical analysis the data were weighted according to the sampling design using Stata software version 10.0 (Stata Corporation, College Station, Texas, USA).

\section{Results}

The final sample included 2352 participants (1116 men and 1236 women) with a mean age of 37.6 years $(\mathrm{SD}=$ 14.3 ), range 18 to 97 years; the household response rate was $80 \%$ and the individual response rate was $90 \%$. Average item missing rates were less than $1 \%$ (range $0-1.8 \%$ ) for the responsiveness questions. Of the 2352 interviewees, $656(28.3 \%)$ reported in-patient care in the five years prior to the survey. Of these, $72.2 \%$ attended a government public facility, $24.3 \%$ a privately operated health 
Table 3: Percentage of patients who experienced some type of discrimination by public and private out-patient care

\begin{tabular}{|c|c|c|c|c|}
\hline Reason for discrimination & Total & Public & Private & OR $(95 \% \mathrm{Cl})$ \\
\hline \multicolumn{5}{|l|}{ Out-patient care } \\
\hline Sex & 3.3 & 4.9 & 0.7 & \\
\hline Age & 5.9 & 8.8 & 1.3 & \\
\hline Lack of money & 11.9 & 15.9 & 5.3 & \\
\hline Social class & 9.3 & 13.3 & 3.0 & \\
\hline Race & 6.4 & 7.8 & 4.2 & \\
\hline Type of illness & 6.3 & 9.0 & 2.0 & \\
\hline Nationality & 4.3 & 5.7 & 2.1 & \\
\hline Total (Mean, range 0-7) & 0.44 & 0.57 & 0.21 & $\begin{array}{l}\text { Private }=1.00 \\
\text { Public }=1.49(1.09-2.03)^{*}\end{array}$ \\
\hline
\end{tabular}

facility, $1.3 \%$ an NGO and $2.4 \%$ other. Among the participants, 449 (19.4\%) had received outpatient care at least once in the year prior to the interview. Of these, 58.7\% attended a government public facility, 35.7\% a privately operated health facility, $0.9 \%$ an NGO and $4.7 \%$ other. Overall, 5.1\% reported to have health insurance. The type of the last out-patient health care provider visited was $52.6 \%$ medical doctor, 36.9\% nurse, 5.5\% dentist, $2.5 \%$ physiotherapist and $2.4 \%$ other, none indicated traditional health practitioner.

According to the evaluation of out-patient care (see Table 1), "waiting time for care" showed the lowest degree of responsiveness (51.2\%) among all the areas analyzed. While, the aspects related to health professionals' skills (92.3\%), adequate equipment $(91.6 \%)$, adequate availability of medicines received $(87.1 \%)$, and respect for intimacy during physical examination (77.9\%) had the highest responsiveness scores. The percentage of users who gave "good" or "very good" ratings was lower among users of the public health care system for all aspects studied, both for out-patient and inpatient care. The percentage of users who rated their experiences with "bad" or "very bad" was $16.8 \%$ for public and $3.2 \%$ for private outpatient care (see Table 1).

Table 4: Percentage of patients who experienced some type of discrimination by public and private in-patient care

\begin{tabular}{|c|c|c|c|c|}
\hline Reason for discrimination & Total & Public & Private & OR $(95 \% \mathrm{Cl})$ \\
\hline Sex & 2.2 & 2.8 & 0.3 & \\
\hline Age & 3.1 & 3.9 & 0.3 & \\
\hline Lack of money & 8.2 & 10.4 & 1.5 & \\
\hline Social class & 6.8 & 8.6 & 1.7 & \\
\hline Race & 7.0 & 8.3 & 3.2 & \\
\hline Type of illness & 4.4 & 5.6 & 0.6 & \\
\hline Nationality & 2.1 & 2.3 & 1.6 & \\
\hline Total (Mean, range 0-7) & 0.35 & 0.43 & 0.11 & $\begin{array}{l}\text { Private }=1.00 \\
\text { Public }=1.80(1.17-2.76)^{* *}\end{array}$ \\
\hline
\end{tabular}


Table 5: Principal component analysis with varimax rotation of health care responsiveness by out-patient and in-patient care (only items loading .40 or more are recorded)

\begin{tabular}{|c|c|c|c|c|c|c|c|c|}
\hline & \multirow[b]{2}{*}{ Frequency (\%) } & \multicolumn{3}{|c|}{ Out-patient experiences } & \multicolumn{4}{|c|}{ In-patient experiences } \\
\hline & & Factor I & Factor 2 & Factor 3 & Factor I & Factor 2 & Factor 3 & Factor 4 \\
\hline & $\begin{array}{l}\text { Out-patient = } \\
\text { OP } \\
\text { In-patient = IP }\end{array}$ & $\begin{array}{l}\text { Time/ } \\
\text { Communication } \\
\text { /Autonomy }\end{array}$ & $\begin{array}{l}\text { Dignity/ } \\
\text { Confidentiality/ } \\
\text { Basic amenities }\end{array}$ & $\begin{array}{l}\text { Health } \\
\text { problem } \\
\text { solution }\end{array}$ & $\begin{array}{l}\text { Communication/ } \\
\text { Autonomy/ } \\
\text { Confidentiality }\end{array}$ & Time/dignity & $\begin{array}{l}\text { Health } \\
\text { problem } \\
\text { solution }\end{array}$ & $\begin{array}{l}\text { Basic } \\
\text { amenities/ } \\
\text { support }\end{array}$ \\
\hline $\begin{array}{l}\text { Traveling time to } \\
\text { the health care } \\
\text { provider }\end{array}$ & $\begin{array}{l}\text { Time } \\
\mathrm{OP}=57.9\end{array}$ & .40 & & & & .69 & & \\
\hline Waiting time & $\mathrm{IP}=65.6$ & .49 & & & & .76 & & \\
\hline $\begin{array}{l}\text { Being greeted and } \\
\text { talked to } \\
\text { respectfully }\end{array}$ & Dignity & & .55 & & & .60 & & \\
\hline $\begin{array}{l}\text { Respect for } \\
\text { intimacy during } \\
\text { physical } \\
\text { examination }\end{array}$ & $\begin{array}{l}\mathrm{OP}=7 \mathrm{I} .4 \\
\mathrm{IP}=74.3\end{array}$ & & .72 & & & .49 & & \\
\hline $\begin{array}{l}\text { Clarity of } \\
\text { explanations }\end{array}$ & Communication & .73 & & & .73 & & & \\
\hline $\begin{array}{l}\text { Time for } \\
\text { questions }\end{array}$ & $\begin{array}{l}O P=68.9 \\
I P=67.0\end{array}$ & .80 & & & .77 & & & \\
\hline $\begin{array}{l}\text { Possibility of } \\
\text { obtaining } \\
\text { information on } \\
\text { other types of } \\
\text { treatment }\end{array}$ & $\begin{array}{l}\text { Autonomy } \\
\mathrm{OP}=59.5 \\
\mathrm{IP}=60.9\end{array}$ & .79 & & & .76 & & & \\
\hline $\begin{array}{l}\text { Participation in } \\
\text { treatment } \\
\text { decision-making }\end{array}$ & & .80 & & & .70 & & & \\
\hline $\begin{array}{l}\text { Privacy with } \\
\text { health } \\
\text { professionals }\end{array}$ & Confidentiality & & .53 & & .70 & & & \\
\hline $\begin{array}{l}\text { Confidentiality of } \\
\text { personal } \\
\text { information }\end{array}$ & $\begin{array}{l}O P=73.6 \\
I P=73.2\end{array}$ & & .58 & & .53 & & & \\
\hline $\begin{array}{l}\text { Cleanliness inside } \\
\text { the health facility }\end{array}$ & $\begin{array}{l}\text { Quality of basic } \\
\text { amenities }\end{array}$ & & .80 & .55 & & & & .66 \\
\hline $\begin{array}{l}\text { Available space in } \\
\text { waiting and } \\
\text { examination } \\
\text { rooms }\end{array}$ & $\begin{array}{l}\mathrm{OP}=68.0 \\
\mathrm{IP}=70.2\end{array}$ & & .72 & & & & & .68 \\
\hline $\begin{array}{l}\text { Satisfactory health } \\
\text { care provider } \\
\text { skills }\end{array}$ & $\begin{array}{l}\text { Health problem } \\
\text { solution } \\
\mathrm{OP}=90.3 \\
\mathrm{IP}=91.7\end{array}$ & & & .78 & & & .85 & \\
\hline
\end{tabular}


Table 5: Principal component analysis with varimax rotation of health care responsiveness by out-patient and in-patient care (only items loading .40 or more are recorded) (Continued)

\begin{tabular}{|c|c|c|c|c|c|c|c|c|}
\hline $\begin{array}{l}\text { Adequate } \\
\text { equipment }\end{array}$ & & & & .88 & & & .89 & \\
\hline $\begin{array}{l}\text { Adequate } \\
\text { availability of } \\
\text { medicines }\end{array}$ & & & & .74 & & & .76 & \\
\hline $\begin{array}{l}\text { Ease of receiving } \\
\text { visitors }\end{array}$ & $\begin{array}{l}\text { Support } \\
I P=68.2\end{array}$ & & & & & & & .67 \\
\hline $\begin{array}{l}\text { Ease of staying in } \\
\text { contact with } \\
\text { outside world }\end{array}$ & & & & & & & & .49 \\
\hline Summary & $\begin{array}{l}O P=67 \\
I P=68\end{array}$ & & & & & & & \\
\hline Variance (\%) & & 38.6 & 12.5 & 7.4 & 37.1 & 11.7 & 8.0 & 6.2 \\
\hline
\end{tabular}

Among all the aspects of in-patient care responsiveness (Table 2), the lowest percentage of responsiveness was attributed to "freedom to choose the health care provider" $(55.7 \%)$, while areas related to adequate health care provider skills, equipment, and availability of medicines had the highest health system responsiveness.

A significant proportion of out-patient care users experienced discrimination for the following reasons: $11.9 \%$ reported feeling they had been treated worse than others because of lack of money and $9.3 \%$ because of their social class. Among users of the public services these figures were $15.9 \%$ and $13.3 \%$, respectively. Of all users, $6.4 \%$ reported they had been treated worse because of their skin colour. Interviewees who had been hospitalized in the previous five years reported lower discrimination rates than out-patients, with "lack of money", race and "social class" as major factors. Users of in-patient and out-patient public health care reported significantly higher discrimination rates than private health care patients (see Table 3 and 4 ).

Principal component analysis found for out-patient care responsiveness three main factors explaining $58.5 \%$ of the variance and for in-patient care responsiveness four factors explaining $62.9 \%$ of the variance. The three factors for out-patient care responsiveness included 1) six items with two each on time, communication and autonomy (explaining $38.6 \%$ of the variance), 2) six items with each two items on dignity, confidentiality and quality of basic amenities (explaining $12.5 \%$ of the variance), and 3 ) three items on health problem solution (explaining $7.4 \%$ of the variance). The four factors for the in-patient care satisfaction included 1) six items with two each on communication, autonomy and confidentiality (explaining $37.1 \%$ of the variance), 2) four items with two each on time and dignity (explaining $11.7 \%$ of the variance), 3 ) three items on health problem solution (explaining $8.0 \%$ of the variance), and 4) four items with two each on quality of basic amenities and access to family and community support (explaining $6.2 \%$ of the variance). The overall responsiveness score was for out-patients $67 \%$ and for inpatients $68 \%$ (see Table 5).

The results of the multivariate analysis of the joint influence of sex, age group, formal education, public versus private health care, and discrimination experience on health care responsiveness are presented in Table 6. Only private health service and lower discrimination experienced were consistently associated with the total patient satisfaction score.

\section{Discussion}

The study conducted among a nationally representative sample in South Africa found that of those who attended in-patient care $72.2 \%$ attended a public and $24.3 \%$ a private facility, and of those who attended out-patient care $58.7 \%$ attended a public and $35.7 \%$ a private facility, none indicated traditional health practitioner. Similarly, Shisana et al. [3] found in a nationally representative study that the majority (70\%) indicated that they usually attended public health care services, $23.3 \%$ attended private health care services, and $0.1 \%$ utilised traditional health practitioners.

The international comparison of health care responsiveness using the same measures and analysis found that overall South Africa (67\% for out-patients and 68\% for inpatients) had much lower responsiveness than Brazil ( $80 \%$ for out-patients and $76 \%$ for in-patients) and Israel and 14 European countries (81\% and higher) for both out-patient and in-patient care. Looking at different com- 
Table 6: Multivariate linear regression of demographic and health variables on total patient satisfaction [Dependent Variable: Ambulatory or in-patient responsiveness]

\begin{tabular}{|c|c|c|c|c|}
\hline & Out-patients & & In-patients & \\
\hline & Total patient satisfaction & & Total patient satisfaction & \\
\hline & Coef. (Cl 95\%) & $P$ & Coef. (Cl 95\%) & $P$ \\
\hline \multicolumn{5}{|l|}{ Sex } \\
\hline Male & $-.21(-1.02-0.61)$ & 0.61 & $-.43(-1.17-.30)$ & 0.24 \\
\hline \multicolumn{5}{|l|}{ Female } \\
\hline \multicolumn{5}{|l|}{ Age } \\
\hline $18-39$ & $.04(-.83-0.91)$ & 0.93 & $.14(-.59-.86)$ & 0.71 \\
\hline \multicolumn{5}{|c|}{40 and more } \\
\hline \multicolumn{5}{|l|}{ Education } \\
\hline $1-3$ & $.23(-.69-1.14)$ & 0.62 & $.77(-.08-1.62)$ & 0.07 \\
\hline $4-7$ & & & & \\
\hline \multicolumn{5}{|c|}{ Form of payment } \\
\hline Public & $-3.20(-4.07--2.33)$ & .000 & $-3.95(-4.73--3.18)$ & 0.000 \\
\hline \multicolumn{5}{|l|}{ Private } \\
\hline \multicolumn{5}{|c|}{ Discrimination } \\
\hline Yes & $-3.90(-5.03--2.78)$ & .000 & $-3.99(-5.02--2.95)$ & 0.000 \\
\hline No & & & & \\
\hline
\end{tabular}

ponents of responsiveness, South Africa scored particularly low on waiting time ( $58 \%$ for out-patients and $66 \%$ for in-patients) and autonomy (60\% for out-patients and $61 \%$ for in-patients) care compared to Brazil (65\% and $69 \%$ for out-patient and in-patient experiences respectively for waiting time and $70 \%$ and $66 \%$ respectively for autonomy), Israel (69\% and $77 \%$ for waiting time and $80 \%$ and $79 \%$ for autonomy) and European countries ( $72 \%$ and $81 \%$ for waiting time and $83 \%$ and $72 \%$ for autonomy. The relative rankings of the domains among out-patients were similar in South Africa and Brazil, with the three highest rankings on confidentiality, dignity and communication, and the three lowest on waiting time, autonomy and quality of basic amenities. Regarding relative rankings on the domains among out-patients rankings were similar in South Africa and Brazil, with quality of basic amenities ranking third, after dignity and confidence. Rankings for European countries were similar, with the exception that quality of basic amenities was ranked higher than in middle income countries (Brazil and South Africa) (see Table 7) [13-15].

Principal component analysis found in this study that responsiveness in out-patients included as major factors waiting time/communication/autonomy followed by dignity/confidentiality/basic amenities, and for in-patients communication/autonomy/confidentiality, waiting time/ dignity and lastly quality of basic amenities/support. Sim- ilarly, Valentine, Darby and Bonsel [16] found from general population surveys of "health systems responsiveness" in 41 countries that most respondents selected prompt attention as the most important domain. Dignity was selected second, followed by communication. Access to social support networks was identified as the least important domain. The factor solutions from this study did not confirm the domain structure of 7 domains of previous studies [17]. This study underlines different clustering patterns of responsiveness for out-patients and in-patients in South Africa, in the Brazilian WHYS study [13] and in a study in Taiwan that found five factors (respect, access, confidentiality, basic amenities, and social support) [18]. For example, "autonomy" was in this and the Taiwanese study [18] not conceptualized as a unique domain. Further, studies are needed to identify the structure of health systems responsiveness domains in developing countries.

Regarding health care provider skills among out-patients in this study similar results were found between this study and the Brazilian WHS: $92.3 \%$ and $92.9 \%$ respectively, adequate equipment $91.3 \%$ and $91.6 \%$ respectively, and adequate availability of medicines $80.8 \%$ and $87.1 \%$, and also among inpatients $91.3 \%$ and $93.7 \%$ for satisfactory health care provider skills, $92.3 \%$ and $91.8 \%$ for adequate equipment, and 92.9 and 89.7 for availability of medicine [13]. 
Table 7: Health care responsiveness (percentage of respondents who responded either "good" or "very good") comparisons across countries [13-15]

\begin{tabular}{lllllllll}
\hline \multicolumn{7}{c}{ Out-patient experiences } & \multicolumn{7}{c}{ In-patient experiences } \\
\hline & South Africa & Brazil & Israel & European countries* & South Africa & Brazil & Israel & European countries* \\
\hline Time & 58 & 65 & 69 & 72 & 66 & 69 & 77 & 81 \\
\hline Dignity & 71 & 93 & 92 & 90 & 74 & 90 & 90 & 89 \\
\hline Communication & 69 & 81 & 87 & 87 & 67 & 76 & 87 & 82 \\
\hline Autonomy & 60 & 70 & 80 & 83 & 61 & 66 & 79 & 72 \\
\hline Confidentiality & 74 & 90 & 88 & 89 & 73 & 80 & 83 & 82 \\
\hline Quality of basic amenities & 68 & 80 & 90 & 91 & 70 & 80 & 60 & 87 \\
\hline Support & & 80 & 83 & 87 & 68 & 70 & 91 & 92 \\
\hline Summary & 67 & 80 & 68 & 76 & 81 & 83 \\
\hline
\end{tabular}

*European countries included were: Austria, Belgium, Denmark, Finland, France, Germany, Greece, Ireland, Italy, Luxemburg, Netherlands, Portugal, Sweden, and United Kingdom

Major components identified for out-patient care responsiveness in this survey were highly correlated with health care access, communication and autonomy, secondarily to dignity, confidentiality and quality of basic amenities, and thirdly to health problem solution. Thus, from the perspective of health service users in South Africa, health care responsiveness was primarily related to health care access, communication and autonomy. Each of the three components got the lowest responsiveness ratings (59\%$77 \%$ ) compared to the other components (dignity, confidentiality, basic amenities and health problem solution) (76\%-84\%).

The degree of responsiveness with publicly provided care was in this study significantly lower than in private health care; a finding which was also found in local studies $[2,8]$ and in the Brazilian WHS [13]. Overall lack of responsiveness for the public out-patient service was $16.8 \%$ in this study, which is lower to the DHS survey (23.3\%) measuring patient dissatisfaction [2]. Both studies were conducted in the same year, 2003. Possible explanations for the above differences may lie in the better quality of private services or that expectations are already high among the population, both for users and nonusers, and because the different measures used in terms of getting a lower score with the responsiveness measure as compared to a dissatisfaction measure. In this study $15.4 \%$ of public outpatients were dissatisfied with the availability of medicines, which seem lower than in some local studies, $56.8 \%$ [9]. In multivariate regression analysis sex, age and educational level were not found to be associated with health care responsiveness unlike in some other studies $[7,11,13,17]$.

Another problem identified in this study and also confirmed in the Brazilian WHS [13] was the high percentage of individuals who felt discrimination, regardless of public or private health care. Discrimination was also one of the principal reasons for dissatisfaction in all aspects of provided health care. The principal sources of discrimination identified by respondents were lack of money, social class and race. Gueveiva et al. [13] also found among the Brazilian WHS lack of money and social class as major factors of health care discrimination. It is important to note that the percentages of individuals who felt they had been treated worse than others on grounds of social exclusion were consistently higher among users of the public health care system, a practice that runs counter to the Bhato Pele (People first) guiding principles of the South African health care system. According to a qualitative study by Mashego and Peltzer [19] discrimination was also identified among primary public care users.

Unlike in some other studies [7], this study did not find significant associations between socio-demographic variables (age, sex and formal education) and patient satisfaction.

\section{Conclusion}

Health care access, communication, autonomy, and discriminatory experiences were identified as priority areas for actions to improve responsiveness and patient satisfac- 
tion in South Africa. Implications for policymaking include that the result from the survey can be used to prioritize efforts when resources are limited. The data seem to provide a clear message to prioritize reforms that improve prompt attention, but not at the expense of patient dignity and communication, which may damage the acceptability of health services to users, and result in barriers to access.

\section{Study limitations}

In this survey all respondents who had been hospitalized in the five years prior to the survey were asked about their most recent hospitalization, and all others were asked about their most recent ambulatory visit in the previous year. The result is that the set of respondents who answered the questions about ambulatory care is small and not representative of the general population, but rather of the population that had not been hospitalized during the previous five years. The cross-sectional study design did not permit an investigation of the cause-effect relationship between responsiveness and independent variables. Recall bias of study participants cannot be excluded, especially on the 5 year recall period for hospital admission.

\section{Competing interests}

The author declares that they have no competing interests.

\section{Authors' contributions}

KP designed the study, conducted the secondary analysis, and drafted and corrected the paper.

\section{Acknowledgements}

The paper uses data from the WHO World Health Surveys Study.

\section{References}

I. Viljoen R, Heunis C, van Rensburg EJ, van Rensburg D, Engelbrecht M, Fourie A, Steyn F, Matebesi Z: National primary health care facilities survey. Bloemfontain: Centre for Health Systems Research \& Development, University of the Free State; 2000.

2. Department of Health: South African Demographic and Health Survey 2003. Pretoria: Department of Health; 2007.

3. Shisana O, Rehle T, Simbayi LC, Parker W, Zuma K, Bhana A, Connolly C, looste J, Pillay V: South African national HIV prevalence, HIV incidence, behaviour and communication survey. Cape Town: HSRC Press; 2005.

4. Department of Health: Primary health care progress report: health monitoring and evaluation. Pretoria: Department of Health; 2000.

5. Department of Public Services and Administration: Transforming Public Service, Delivery White Paper (Batho Pele White Paper), (Gazette 18340 Notice 1459). Pretoria, South Africa: Department of Public Services and Administration; 1997.

6. Goldstein S, Price M: Utilisation of primary curative services in Diepkloof, Soweto. S Afr Med J 1995, 85(6):505-8.

7. Van Vuuren SJEJ, Botes LJS: Attitudes towards health care in greater Bloemfontein. Curationis 1994, 17:2-10.

8. Peltzer K: Community perceptions of biomedical health care in a rural area in the Limpopo Province South Africa. Health SA Gesondheid 2000, 5(I):55-63.

9. Bediako MA, Nel M, Hiemstra LA: Patients' satisfaction with government health care and services in the Taung district, North West Province. Curationis 2006, 29(2):12-5.
10. De Jager J, Du Plooy T: Service quality assurance and tangibility for public health care in South Africa. Acta Commercii 2007, 7:96-17.

II. Myburgh NG, Solanki GC, Smith MJ, Lalloo R: Patient satisfaction with health care providers in South Africa: the influences of race and socioeconomic status. Int J Qual Health Care 2005, 17(6):473-7.

12. Üstun TB, Chatterji S, Villanueva M, Celik LBC, Sadana R, Valentine N, Oritz J, Tandon A, Salomon J, Cao Y, Wan Jun X, Özaltin E, Mathers C, Murray CJL: Multi-country Survey Study on Health and Responsiveness 2000-200 I. Geneva: World Health Organization; 200I. GPE Discussion Paper 37

13. De Souza WV, Luna CF, De Souza-Júnior PRB, Szwarcwald CL: Health care users' satisfaction in Brazil, 2003. Cad Saúde Pública 2005, 2 I(Sup):S109-I I8.

14. Valentine NB, Ortiz JP, Tandon A, Kawabata K, Evans DB, Christopher JL, Murray CJL: Patient experiences with health services: population surveys from I6 OECD countries. In Health systems performance assessment: debates, methods and empiricism Edited by: Murray CJL, Evans DB. Geneva: WHO; 2003:643-652.

15. Goldwag R, Rosen B: Responsiveness of the health care system: findings from the Israeli component of the World Health Survey. Jerusalem: Myers-JDC-Broodale Institute; 2007.

16. Valentine N, Darby C, Bonsel GJ: Which aspects of non-clinical quality of care are most important? Results from WHO's general population surveys of "health systems responsiveness" in 41 countries. Soc Sci Med 2008, 66(9):1939-50.

17. Valentine NB, Bonsel G], Murray CJ: Measuring quality of health care from the user's perspective in $4 I$ countries: psychometric properties of WHO's questions on health systems responsiveness. Qual Life Res 2007, I 6(7): I I 07-25.

18. Hsu CC, Chen L, Hu YW, Yip W, Shu CC: The dimensions of responsiveness of a health system: a Taiwanese perspective. BMC Public Health 2006, I7(6):72.

19. Mashego T-AB, Peltzer K: Community perception of quality of (primary) health care services in a rural area of Limpopo Province, South Africa: a qualitative study. Curationis 2005, 28(2):|3-2|.

\section{Pre-publication history}

The pre-publication history for this paper can be accessed here:

\section{http://www.biomedcentral.com/1472-6963/9/117/pre} pub
Publish with Bio Med Central and every scientist can read your work free of charge

"BioMed Central will be the most significant development for disseminating the results of biomedical research in our lifetime. "

Sir Paul Nurse, Cancer Research UK

Your research papers will be:

- available free of charge to the entire biomedical community

- peer reviewed and published immediately upon acceptance

- cited in PubMed and archived on PubMed Central

- yours - you keep the copyright

Submit your manuscript here:

http://www.biomedcentral.com/info/publishing_adv.asp
BioMedcentral 